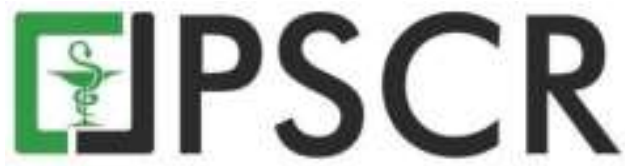

\title{
Penelusuran dan Isolasi Fungi Tanah Muara Pelabuhan Besuki Serta Skrining Aktivitas Antibakteri Terhadap Pseudomonas aeruginosaATTCC 27853
}

\author{
Mariatul Kibthiyyah, Bawon Triatmoko, dan Ari Satia Nugraha* \\ Drug Utilisation and Discovery Research Groups, Fakultas Farmasi, Universitas Jember, Jl. Kalimantan 1/2, \\ Jember, Indonesia, 68121 \\ *email korespondensi: arisatia@unej.ac.id \\ Received 10 November 2021, Accepted 7 June 2021, Published 15 July 2021
}

\begin{abstract}
Abstrak:Penyakit infeksi merupakan salah satu penyebab utama kematian di dunia. Terapi infeksi bakteri dengan antibiotik yang tidak tepat penggunaannya dapat menyebabkan resistensi. Penemuan antibiotik baru dapat berasal dari bahan alam, salah satunya fungi. Penelitian ini bertujuan untuk mengetahui aktivitas antibakteri ekstrak etil asetat hasil fermentasi fungi khamir tanah muara terhadap Pseudomonas aeruginosa. Isolasi fungi tanah dilakukan menggunakan media Potato dextrose Agar (PDA) dilarutkan dalam air laut. Proses tersebut menghasilkan 7 isolat fungi kemudian disebut IS-PB-A1, IS-PB-A2, IS-PB-A3, ISPB-T1, IS-PB-T2, IS-PB-B1, IS-PB-B2. Semua isolat fungi memiliki potensi dalam menghambat pertumbuhan bakteri dengan uji antagonis. Pengujian aktivitas antibakteri dilanjutkan menggunakan metode mikrodilusi. Aktivitas antibakteri disajikan dalam bentuk persen penghambatan. Hasil uji antibakteri dari tujuh ekstrak konsentrasi $100 \mu \mathrm{g} / \mathrm{mL}$ menunjukkan persen penghambatan tertinggi dari kode IS-PB-A2 $(84,7 \pm 1,4 \%)$ dan terendah dari kode IS-PB-T2 $(30,5 \pm 3,3 \%)$. Senyawa yang berperan menghambat pertumbuhan bakteri dalam penelitian ini belum bisa dipastikan sehingga diperlukan penelitian lebih lanjut.
\end{abstract}

Kata kunci:Antibakteri; Pseudomonas aeruginosa;Fungi Tanah

\begin{abstract}
Tracking and Isolation Estuary Soil Fungi in Harbor of Besuki and Screening Antibacterial Activities on Pseudomonas aeruginosa. Infectious disease is one of the causes of death worldwide. Inapprorpate antibiotis treatment for bacterial infections auses resistance.New antibiotics can be sourced from nature including fungi. This study aims to determine the antibacterial activity of ethyl acetate extract from fermented estuarine yeast against Pseudomonas aeruginosa.Isolation of soil fungi using Potato dextrose Agar (PDA) media dissolved in sea water. This process resulted in 7 isolates of the fungus which were then called IS-PB-A1, IS-PB-A2, IS-PB-A3, IS-PB-T1, IS-PB-T2, IS-PB-B1, IS-PB-B2. All fungal isolates have the potential to inhibit bacterial growth with antagonistic tests. Antibacterial activity testing was continued using the microdilution method.The antibacterial activity test were performed based on microdilution protocol. The antibacterial activity is presented in the form of percent inhibition. Antibacterial test results from seven extracts of concentration of $100 \mu \mathrm{g} / \mathrm{mL}$ showed the highest inhibitory percent of the IS-PB-A2 code $(84.7 \pm 1.4 \%)$ and the lowest from the IS-PB-T2 code $(30.5 \pm 3.3 \%)$. The compounds that play a role in inhibiting bacterial growth in this study cannot be ascertained so further research is needed
\end{abstract}

Keywords:Antibacterial; Pseudomonas aeruginosa; Soil Fungi 


\section{Pendahuluan}

Masalah kesehatan di negara berkembang yang kerap menyebabkan kematian di seluruh dunia salah satunya adalah penyakit infeksi (Mustaqof et al., 2015). World Health Organization (WHO)melaporkan bahwa pada tahun2017penyakit infeksi menyebabkan 17\% dari semua kematian di seluruh dunia terutama balita (WHO, 2017). Penyakit infeksi disebabkan oleh mikroorganisme patogen, seperti virus, bakteri, parasit atau jamur (Nursidika et al., 2014).Antibiotik merupakan salah satu agen untuk memerangi penyakit infeksi yang disebabkan bakteri dengan menghambat sintesis sel, sintesis protein, asam deoksiribonukleat,dan asam ribonukleat(Stuart,2014). Penggunaan antibiotik yang kurang tepat telah memberikan kontribusi signifikan terhadap munculnya kasus resistensi.Resistensi menyebabkan obat kehilangan kemampuan untuk menghambat pertumbuhan bakteri sehingga bakteri menjadi "tahan" dan terus berkembang biak. Resistensi tersebut membuat penemuan alternatif antibiotik baru untuk melawan penyakit infeksi akibat bakteri menjadi sangat diperlukan (Zaman et al., 2017). Penemuan antibiotik tersebut dapat bersumber dari fungi tanah seperti Saccharomyces sp,Cryptococcus sp, Candida sp, dan spesies fungi lain dalam tanah.

Penelitian terkini terkait penemuan aktivitas antibakteri yang diisolasi dari fungi dilakukan oleh Wibowo (2017). Penelitian tersebut menunjukkan adanya aktivitas antibakteri dari fungi yang diisolasi dari tanah berasal dari Shah Alam Malaysia terhadap B. subtilisdan E. coli. Penelitian lain juga dilakukan oleh Anupama et al(2017) yang melaporkan adanya aktivitas antibakteri dari Candida sp. yang diisolasi dari tanah terhadap bakteri Staphylococcus sp. dan Bacillus sp. yang ditunjukkan dengan adanya zona hambat pada media agar menggunakan metode difusi cakram. Salah satu ekosistem tempat tumbuhnya fungi penghasil antibiotik adalah tanahmuara. Potensi antibakteri fungi tanah yang berasal dari kawasan pantai pasir putih Situbondo Kecamatan Bungatan sebelumnya telah diteliti (Pamungkas, 2021). Berdasarkan letak pengambilan sampel pada penelitian tersebut pada jarak 18,7 km terdapat pelabuhan Besuki. Potensi antibakteri fungi tanah muara di pelabuhan tersebut tidak pernah diteliti sebelumnya.

Muara dicirikan dengan gradien salinitas dalam sistem pesisir semi tertutup yang menghasilkan evolusi sekelompok organisme yang unik dan mampu beradaptasi menggunakan gradien salinitas sebagai keunggulan kompetitif dengan kemampuan osmoregulator yang baik (Elliott \& Whitfield, 2011).Fungi tanah mampu mendegradasi selulosa, protein, dan lignin, tahan terhadap kerusakan serta dapat menghancurkan kayu keras yang ada didalam tanah. Fungi menyerap sebagian hasil penguraian tersebut dan melepaskan 
bahan-bahan sederhana salah satunya metabolit sekunder untuk mempertahankan diri dari kondisi lingkungan yang tidak menguntungkan. Metabolit sekunder inilah yang kemudian dapat dijadikan sebagai sumber penemuan antibiotik baru. Potensi dari bagian ekosistem muara adalah ekosistem bakau yang mencerminkan hubungan timbal balik antara makhluk hidup dengan lingkungannya dan antar makhluk hidup itu sendiri. Ekosistem bakau menjadi habitat kaya akan bahan organik sebagai pendukung pertumbuhan fungi(Entwistle, 2016).

Bakteri penyebab infeksi secara garis besar si dibagi menjadi dua, yaitu bakteri gram positif dan gram negatif. Bakteri gram positif hanya memiliki membran tunggal, sedangkan gram negatif memiliki membran ganda yang terdiri dari lipopolisakarida dan fosfolipid dengan permeabilitas rendah terhadap beberapa senyawa. Hal tersebut menyebabkan gram negatif lebih berbahaya dibanding gram positif (Kramer et al., 2019). Salah satu bakteri gram negatif penyebab infeksi adalah Pseudomonas aeruginosa. Beberapa penelitian di beberapa rumah sakit diIndonesia menyebutkan bahwa penyebab penyakit infeksi terbanyak disebabkan oleh Pseudomonas aeruginosa dengan kejadian sekitar 3,3-30,8\% (Taslim \& Maskoen, 2016). Resistensi bakteri Pseudomonas aeruginosa memicu eksplorasi agen antibakteri baru (Maulanaet al., 2020).

Penelitian ini bertujuan untuk menelusuri dan mengisolasi fungi dari tanah muara Pelabuhan Besuki Kabupaten Situbondo serta menskrining aktivitas antibakterinya terhadapPseudomonas aeruginosa. Parameter aktivitas antibakteri yang digunakan adalah persentase hambat ekstrak etil asetat fungi tanah menggunakan metode mikrodilusi. Studi terkaitidentifikasi fungi dan skrining bioaktivitas terhadap pertumbuhan bakteri diharapkan dapat memberikan pengetahuan lebih banyak tentang keanekaragaman fungi serta untuk memberikan informasi potensi penemuan alternatif antibiotik baru.

\section{Metode Penelitian}

\subsection{Alat}

Laminar Air Flow (THERMO CIENTIFIC 1300 SERIES A2), microplate flat bottom 96 wells (IWAKI),autoclave (B-ONE),microplate reader (HumaReader HS), shaker incubator (B-ONE), neraca analitik (OHAUS), hot plate (HEIDOLPH), vortex (GENE-2), mikropipet (Socorex \& Eppendorf), centrifuge, spektrofotometer UV-Vis (GENESYS) dan chamberkromatografi lapis tipis/KLT (CAMAG).

\subsection{Bahan}

Tanah muara dari Pelabuhan Besuki Kabupaten Situbondo, sterile water for irrigation, aqua demineralisata (HYDROBATT), air laut, larutan $\mathrm{NaCl} 0,9 \%$, Potato Dextrose Agar (PDA) (HIMEDIA), Potato Dextrose Broth(PDB) (HIMEDIA), Mueller Hinton Agar (MHA) 
(Merck), Mueller Hinton Broth (MHB) (HIMEDIA), bakteri Pseudomonas aeruginosa ATCC 27853, DMSO (Emsure), $\mathrm{CaCl}_{2}$ (Sigma), $\mathrm{MgCl}_{2}$ (Brataco), $\mathrm{BaCl}_{2}, \mathrm{H}_{2} \mathrm{SO}_{4}$, etil asetat teknis, dan gentamisin sulfat.

\subsection{Prosedur penelitian}

\subsubsection{Preparasi media}

Media PDA ditimbang sejumlah $1,17 \mathrm{~g}$ dan dilarutkan dengan aqua demineral sebanyak 250 mL.Media PDB ditimbang sebanyak3,60g lalu dilarutkan dalam erlenmeyer dengan 150 $\mathrm{mL}$ aqua demineralisata. Media MHA ditimbang sebanyak 3,40g, dilarutkan dengan aqua demineralisata $150 \mathrm{~mL}$ dalam erlenmeyer. Media MHB ditimbang $1 \mathrm{~g}$ dilarutkan dalam 50 $\mathrm{mL}$ aqua demineralisata. Media CAMHB dibuat dengan media MHB steril ditambahkan $\mathrm{Mg}^{2+}$ dan $\mathrm{CaCl}_{2}$ steril hingga konsentrasi keduanya berturut-turut 10-12,5 mg/L dan 20-25 mg/L (CLSI, 2012). Penambahan larutan induk $\mathrm{Mg}^{2+}$ dan $\mathrm{CaCl}_{2}$ kedalam $50 \mathrm{~mL}$ media $\mathrm{MHB}$ steril masing-masing $56 \mu \mathrm{L}$ untuk $\mathrm{Mg}^{2+}$ dan $110 \mu \mathrm{L}$ untuk $\mathrm{CaCl}_{2}$ sehingga diperoleh konsentrasi 11,25 $\mathrm{mg} \mathrm{Mg}^{2+} / \mathrm{L}$ dan 22,5 $\mathrm{mg} \mathrm{CaCl}_{2} / \mathrm{L}$.

\subsubsection{Preparasi sampel tanah, pembiakan dan isolasi fungi}

Sampel tanah diambil dari muara Pelabuhan Besuki, Kabupaten Situbondo di sekitar tanaman bakau dengan kedalaman 0-40 cm menggunakan pipa PVC. Sampel dibagi tiga bagian yaitu atas, tengah, dan bawah. $5 \mathrm{~cm}$ tanah yang terambil pada bagian atas pipa disebut bagian atas. $5 \mathrm{~cm}$ tanah terbawah pada pipa disebut sambel bagian bawah, sedangkan tanah ditengah-tengah pipa disebut bagian tengah. Sampel disuspensikan dengan air steril $10 \mathrm{~mL}, 2$ $\mathrm{mL}$ dipipet ke microtube lalu disentrifugasi dengan kecepatan 500 rpm selama 15 menit. Bagian supernatan diambil $100 \mu \mathrm{L}$ dan dituang pada media PDA. Fungi yang tumbuh setelah inkubasi pada suhu $28 \pm 2{ }^{\circ} \mathrm{C}$ selama 7 hari dipindah berdasarkan morfologi yang berbeda secara visual pada media PDA yang baru kemudian diinkubasi kembali 7 hari pada suhu $28^{\circ} \mathrm{C}$.

\subsubsection{Identifikasi fungi makroskopis dan mikroskopis}

Identifikasi fungi makroskopis dilakukan dengan pengamatan secara visual fungi yang tumbuh pada media PDA. Identifikasi fungi mikroskopis dilakukan dengan menggunakan mikroskop perbesaran 1000x.

\subsubsection{Pembuatan suspensi bakteri}

Hasil inokulumbakteri uji diambil 1 ose disuspensikan ke dalam tabungreaksi berisi $\mathrm{NaCl}$ fisiologis 0,9\%,lakukanpengenceran hingga menghasilkan absorbansisebesar 0,08 - 0,13 pada spektrofotometerdengan panjang gelombang $625 \mathrm{~nm}$.

\subsubsection{Uji antagonis bakteri}


Isolat fungi pada media PDA dicetak menggunakan sumuran diambil dengan ose dan dikontakkan dengan bakteri ujiPseudomonas aeruginosa, selanjutnya diinkubasi selama 18 jam pada suhu $35 \pm 2^{\circ} \mathrm{C}$ menggunakan inkubator. Dilakukan pengukuran nilai diameter zona bening menggunakan jangka sorong.

\subsubsection{Fermentasi dan ekstraksi fungi tanah}

Fermentasi dilakukan menggunakan metode batch fermentation dengan memasukkan 5 potong bagian kultur fungi yang dicetak dengan sumuran berdiameter $0,9 \mathrm{~cm}$ ke dalam media PDB 150 mL. Campuran keduanya di letakkan pada shaker incubator hingga fungi mencapai fase stationer pada hari ke-14.Ekstraksi dilakukan dengan menyaring hasil fermentasi. Hasil saringan media fermentasi ditambah etil asetat 1:1 dan dilakukan partisi cair-cair selama lima belas menit sebanyak 3 kali replikasi. Hasil ekstraksi dengan etil asetat dituang ke dalam mangkok untuk menguapkan pelarut di dalam lemari asam. Setelah pelarut menguap seutuhnya, esktrak dimasukkan ke dalam vial dan ditimbang bobotnya serta dihitung \% rendemennya.

\subsubsection{Skrining fitokimia}

Skrining fitokimia terhadap ekstrak hasil fermentasi dilakukan guna mengetahui adanya senyawa fenolat dan terpenoid atau steroid. Larutan ekstrak hasil preparasi ditotolkan sebanyak $4 \mu \mathrm{L}$ pada plat KLT $\mathrm{F}_{254}$. Plat KLT tersebut kemudian dieluasi dengan eluen sesuai hasil optimasi. Eluen dianggap optimal ketika menghasilkan pemisahan pada lempeng KLT. Reagen vanilin- $\mathrm{H}_{2} \mathrm{SO}_{4}$ untuk mendeteksi adanya senyawa fenolat yang ditunjukkan dengan warna merah muda, sedangkan untuk terpenoid dapat dideteksi jika ditemukan noda berwarna merah keunguan pada lempeng KLT setelat dilakukan pemanasan pada hot plate(Sharifa et al, 2012).

\subsubsection{Uji aktivitas antibakteri}

Pengujian aktivitas antibakteri fungi tanah dilakukan dengan metode mikrodilusi konsentrasi $100 \mu \mathrm{g} / \mathrm{mL}$ yang mengacu pada protokol standar CLSI M100-S25 (CLSI, 2017). Penentuan aktivitas antibakteri ekstrak etil asetat fungi tanah dilakukan dengan metode mikrodilusi. Suspensi bakteri dalam media CAMHB $\left(1 \mathrm{x} 10^{8} \mathrm{CFU} / \mathrm{mL}\right)$ diencerkan $100 \mathrm{kali}$ menggunakan media CAMHB hingga konsentrasi bakteri menjadi 1 x $10^{6} \mathrm{CFU} / \mathrm{mL}$. Setiap sumuran berisi $50 \mu \mathrm{L}$ suspensi bakteri dalam media CAMHB. Penambahan larutan kontrol positif, kontrol negatif, dan larutan uji masing-masing sebanyak 50 $\mu$ L. Konsentrasi akhir bakteri dalam tiap sumuran $5 \times 10^{4}$ CFU.Uji aktivitas antibakteri ekstrak etil asetat fungi tanah terdiri dari campuran $50 \mu \mathrm{L}$ larutan ekstrak dalam DMSO $1 \%$ dan $50 \mu \mathrm{L}$ bakteri $\left(5 \times 10^{4}\right.$ $\mathrm{CFL} / \mathrm{mL}$ ) dalam media CAMHB. Kontrol ekstrak terdiri dari campuran $50 \mu \mathrm{L}$ larutan ekstrak 


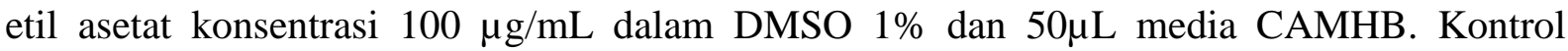
negatif ekstrak terdiri dari campuran $50 \mu \mathrm{L}$ DMSO $1 \%$ dalam media CAMHB dan $50 \mu \mathrm{L}$ bakteri dalam media CAMHB. Kontrol DMSO 1\% yaitu campuran $50 \mu \mathrm{L}$ DMSO $1 \%$ dalam media CAMHB dan $50 \mu \mathrm{L}$ media CAMHB. Kontrol positif terdiri dari $50 \mu \mathrm{L}$ campuran gentamisin konsentrasi $1 \mu \mathrm{g} / \mathrm{mL}$ dan $50 \mu \mathrm{L}$ bakteri dalam media CAMHB. Kontrol gentamisin terdiri dari campuran $50 \mu \mathrm{L}$ gentamisin konsentrasi $1 \mu \mathrm{g} / \mathrm{mL}$ dan $50 \mu \mathrm{L}$ media CAMHB. Campuran media CAMHB $50 \mu \mathrm{L}$ dan bakteri $50 \mu \mathrm{L}$ menjadi kontrol negatif gentamisin, sedangkan media CAMHB $100 \mu \mathrm{L}$ merupakan kontrol media. Semua prosedur uji aktivitas antibakteri dilakukan dalam kondisi aseptis.

\subsubsection{Analisis data}

Persentase pertumbuhan bakteri dihitung berdasarkan rumus persamaan 1 (Queve et al., 2008).

$$
\% \text { Penghambatan }=\left(1-\frac{(\text { Abs } C-A b s D)}{(A b s A-A b s B)}\right) \times 100 \%
$$

Persamaan 1. Persentase pertumbuhan bakteri. Keterangan:Absorbansi (Abs), Kontrol DMSO $1 \%$ atau media CAMHB (A), Kontrol DMSO $1 \%$ atau media CAMHB (B), Larutan uji ekstrak/gentamisin (C) dan Kontrol ekstrak/gentamisin (D).

\section{Hasildan Pembahasan}

\subsection{Pembiakan dan Isolasi Fungi Tanah}

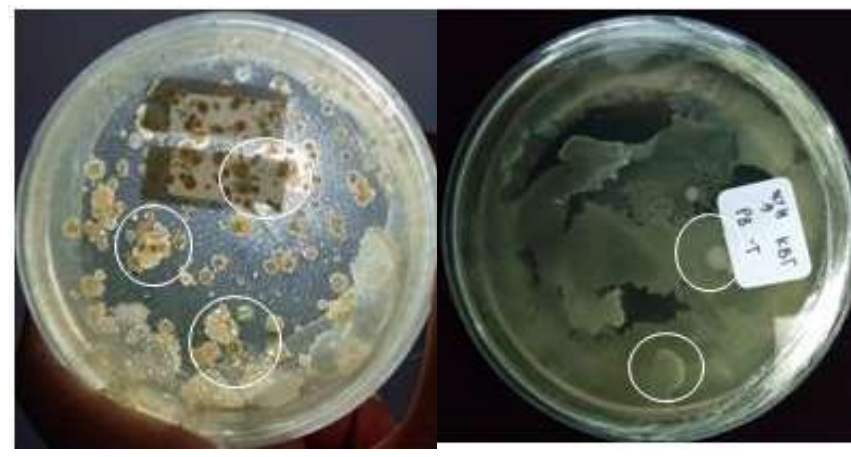

(A)
(B)

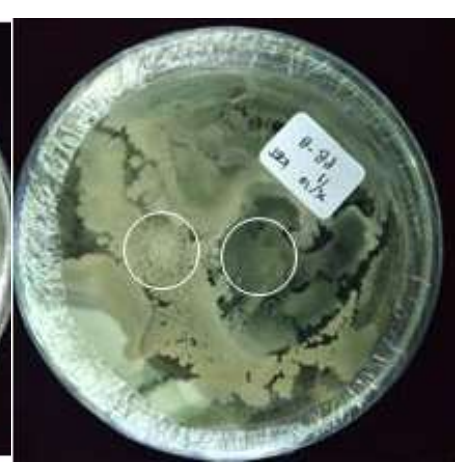

(C)

Gambar 1.Hasil kultur fungi yang berasal dari tanah muara dari pelabuhan Besuki Kabupaten Situbondo selama 7 hari pada media PDA-air laut. Sampel berasal dari tiga bagian tanah yang terambil pada pipa: (A) bagian tanah teratas yang terambil pada pipa, (B) bagian tanah yang terambil pada tengah pipa, (C) bagian tanah terbawah bawah yang terambilpada pipa.

Sampel yang berhasil dikumpulkan dibagi 3 bagian yaitu atas, tengah, dan bawah untuk melihat kemungkinan jenis fungi berbeda di setiap bagian tanah. Hasil pengamatan visual morfologi fungi hasil kultur didapatkan 2 sampai 3 perbedaandari sampel tanah atas, tengah, dan bawah yang disajikan pada Gambar 1. Hasil isolasi fungi tanahsecara makroskopis pada 7 isolat fungi berumur 7 hari ditunjukkan pada Gambar 2. Masing-masing isolate tersebut 
kemudian disebut dengan IS-PB-A1, IS-PB-A2, dan IS-PB-A3 untuk sampel tanah bagian atas, IS-PB-T1 dan IS-PB-T2 untuk sampel tanah bagian tengah, IS-PB-B1 dan IS-PB-B2 untuk sampel tanah bagian bawah.

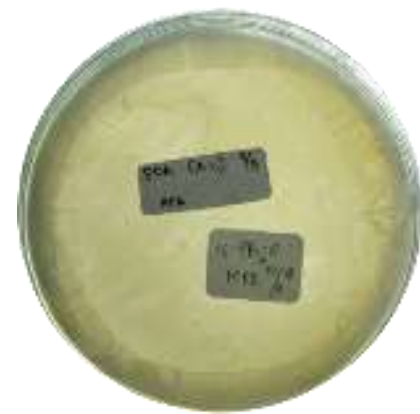

(A)

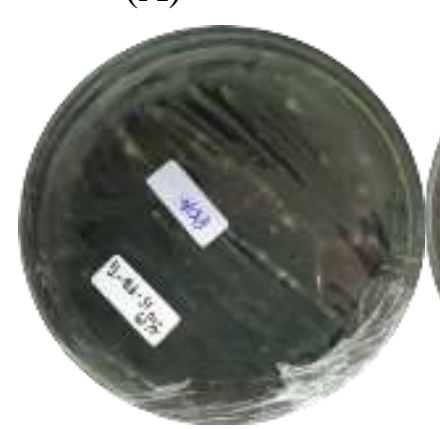

(D)

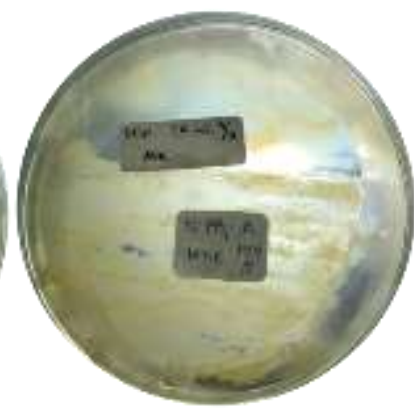

(B)

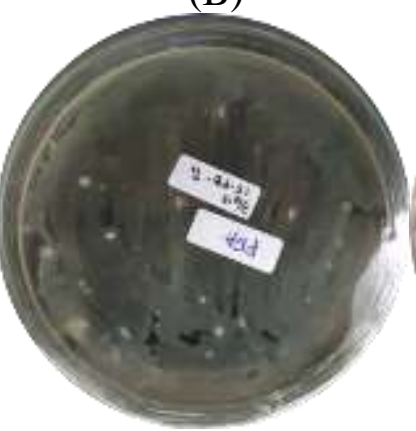

(E)

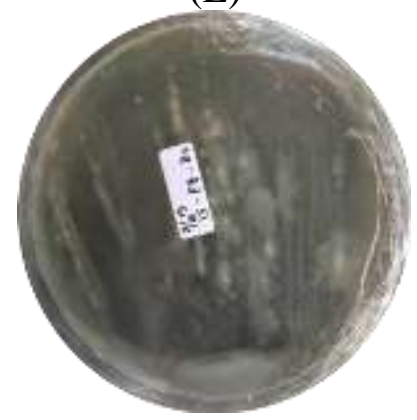

(G)

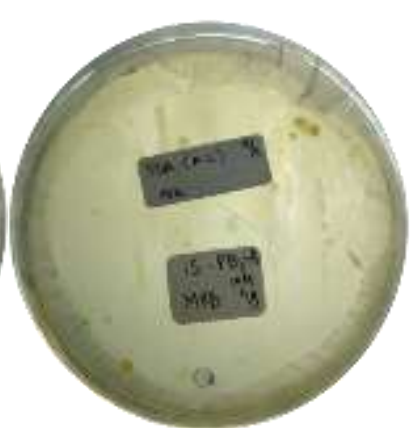

(C)

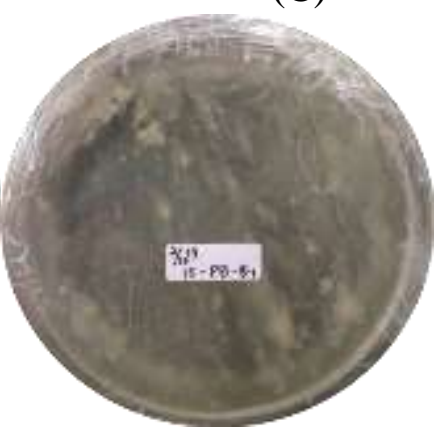

(F)

Gambar 2.Hasil isolasi fungi tanah pada media PDA-air laut. Sampel berasal dari tiga bagian tanah yang terambil pada pipa: kode A1, A2 dan A3 untuk bagian tanah atas yang terambil pada pipa, kode T1 dan T2 untuk bagian tanah yang teambil dibagian tengah pipa, B1 dan B2 utnuk bagian tanah terbawah yang terambil pada pipa. (A) IS-PB-A1, (B) IS-PB-A2, (C) IS-PB-A3, (D) IS-PB-T1, (E) IS-PB-T2, (F) IS-PBB1, (G) IS-PB-B2.

Penambahan air laut pada proses pembiakan diharapkan dapat membuat pertumbuhan fungi menjadi lebih optimum sesuai proses optimasi media pada penelitianPamungkas (2021). Proses isolasi bertujuan untuk memisahkan fungi tanah dari mikroorganisme lain yang tidak dibutuhkan dalam penelitian agar menghasilkan biakan fungi murni. Hasil isolasi tersebut diidentifikasi makroskopis dan mikroskopis untuk memastikan jenis fungi yang tumbuh. Jenis fungi kapang biasanya memiliki warna yang bervariasi dan terdapat hifa sebagai alat 
reproduksi vegetatif sebagai ciri khasnya, sedangkan jenis fungi khamir tumbuh dengan morfologi menyerupai koloni bakteri (Campbell et al., 2003).

\subsection{Identifikasi makroskopis dan mikroskopis}

Hasil isolasi fungi tanah masing-masing diamati secara visual untuk menentukan jenis fungi yang dihasilkan. Rincian morfologi hasil kultur fungi yang diamati secara makroskopis ditunjukkan pada Tabel 1, sedangkan morfologi hasil isolasi fungi secara makroskopis disajikan pada Tabel 2.

Tabel 1.Morfologi hasil kultur fungi tanah berumur 7 hari pada media PDA-air laut secara makroskopis. (A) sampel tanah teratas yang terambil pada pipa, (T) sampel tanah yang terambil dibagian tengah pipa, (B) sampel tanah terbawah yang terambil pada pipa.

\begin{tabular}{ccc}
\hline Kode & \multicolumn{2}{c}{ Karakteristik makroskopis } \\
\cline { 2 - 3 } Sampel & Warna & Tekstur \\
\hline IS-PB-A & Putihkecoklatan, buram, kusam & Halus, kental dan licin \\
IS-PB-T & Putih krem, buram, kusam & Halus, kental \\
IS-PB-B & Putih krem, buram, kusam & Halus, kental \\
\hline
\end{tabular}

Hasil kultur fungi dari bagian tanah atas, tengah, dan bawah cenderung memiliki warna putih krem atau kekuningan, buram dan kusam serta bertekstur halus dan kental (Tabel 2). Hasil isolasi fungi selanjutnya disimpan dalam suhu $10 \pm 2^{\circ} \mathrm{C}$ dengan tujuan memperlambat pertumbuhan fungi untuk penyimpanan lebih lama. Pengamatan morfologi sel bertujuan untuk mengetahui bentuk dan ada tidaknya hifa atau pseudohifa. Fungi khamir dibawah mikroskop menyerupai koloni bakteri dengan bentuk oval atau telur, tetapi beberapa ada yang berbentuk bulat. Sebagian besar sel khamir memiliki ukuran lebih besar dibandingkan bakteri, tetapi khamir yang terkecil tidak sebesar bakteri yang terbesar (Volk \& Wheeker, 1971).

Tabel 2. Morfologi hasil isolasi fungi pada media PDA-air laut. Sampel berasal dari tiga bagian tanah yang terambil pada pipa: kode A1, A2 dan A3 untuk bagian tanah atas yang terambil pada pipa, kode $\mathrm{T} 1$ dan $\mathrm{T} 2$ untuk bagian tanah yang teambil dibagian tengah pipa, B1 dan B2 utnuk bagian tanah terbawah yang terambil pada pipa.

\begin{tabular}{ccc}
\hline \multirow{2}{*}{ Kode Sampel } & \multicolumn{2}{c}{ Karakteristik makroskopis } \\
\cline { 2 - 3 } & Warna & Tekstur \\
\hline IS-PB-A1 & Putih kekuningan, buram, kusam & Halus, kental bermembran \\
IS-PB-A2 & Putih kekuningan, buram, kusam & Halus, kental bermembran \\
IS-PB-A3 & Putih kekuningan, buram, kusam & Halus, kental bermembran \\
IS-PB-T1 & Putih krem, buram, kusam, & Halus, kental \\
IS-PB-T2 & Putih krem, buram, kusam, & Halus, kental \\
IS-PB-B1 & Putih krem, buram, kusam, & Halus, kental \\
IS-PB-B2 & Putih krem, buram, kusam, & Halus, kental \\
\hline
\end{tabular}

Selain pengamatan secara makroskopis, fungi tanah diidentifikasi menggunakan mikroskop untuk memastikan kembali jenis fungi yang dihasilkan melalui pengamatan morfologi sel fungi. Fungi tanah diamati dibawah mikroskop perbesaran 1000x. Pengamatan 
secara mikroskopis dilakukan terhadap semua hasil isolosi fungi tanah atas, tengah dan bawah dengan hasil disajikan pada Gambar 3.

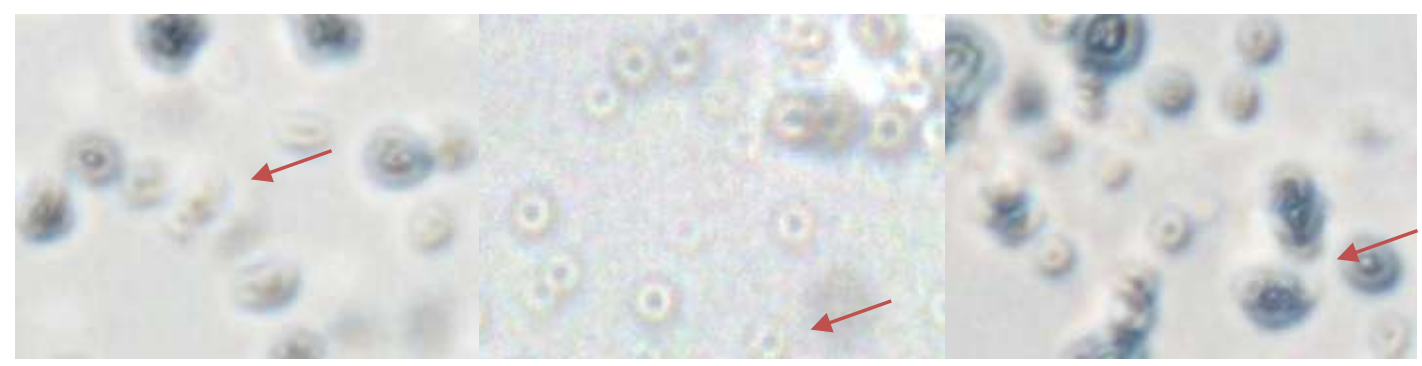

(A)

(B)

(C)

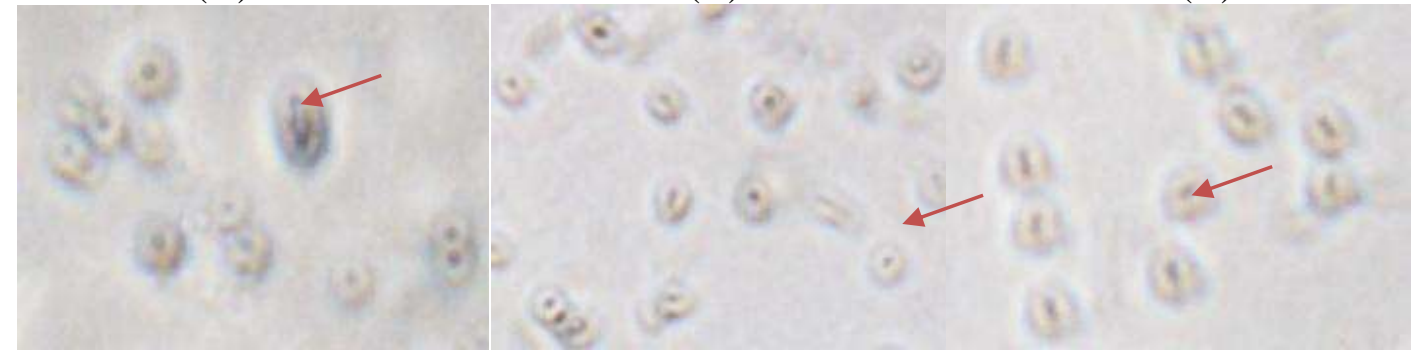

(D)

(E)

(F)

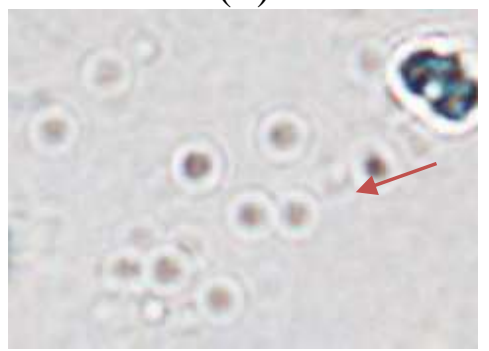

(G)

Gambar 3. Pengamatan bentuk sel fungi khamir sampel fungi tanah, perbesaran 1000x, scale bar $20 \mu \mathrm{m}$ (A) IS-PB-A1 bulat, (B) IS-PB-A2 bulat, (C) IS-PB-A3 bulat, (D) ISPB-T1 bulat, (E) IS-PB-T2 bulat, (F) IS-PB-B1 oval, (G) IS-PB-B2 bulat.

Data hasil pengamatansecara mikroskopis menunjukkan bahwa fungi yang tumbuh dalam media adalah jenis khamir karena memiliki inti sel berbentuk bulat atau oval. Tanah mengandung banyak komponen termasuk fungi dan bakteri yang memiliki bentuk hampir sama yaitu bulat. Bakteri yang sering terkandung di dalam tanah yakni aktinomisetes. Aktinomisetesmerupakan sel prokariotik tak berinti sel, sedangkan fungi jenis khamir dapat dilihat dari ada tidaknya inti sel (Pepper \& Gentry, 2015). Berdasarkan karakteristik tersebut diduga fungi khamir yang berhasil diisolasi dalam penelitian ini termasuk ke dalam spesies Saccharomyces sp, namunpemastian jenis spesies khamir dalam setiap kode sampel belum bisa ditentukan. Identifikasi fungi lebih lanjut diperlukan untuk memastikan spesies khamir. Selain itu untuk mempermudah identifikasi fungi perlu dilakukan pemurnian kembali berdasarkan perbedaan morfologi fungi secara makroskopis agar diperoleh biakan fungi murni mengandung satu spesies dalam satu plate. 


\subsection{Skrining awal fungi tanah}

Skrining awal atau uji antagonis bakteri dilakukan untuk menyeleksi isolat fungi yang mampu menghasilkan daya hambat terhadap pertumbuhan P.aeruginosadengan data disajikan pada Tabel 3. Proses uji antagonis menggunakan metode difusi agar dengan hasil berupa diameter zona hambat.Zona hambat tersebut berupa zona bening yang nampak di sekeliling fungi. Warna bening tersebut menandakan adanya respon penghambatan pertumbuhan bakteri oleh suatu senyawa antibakteridalam fungi.

Tabel 3. Diameter zona hambat sampel hasil isolasi, serta berat dan randemen ekstrak (\%b/v) hasil fermentasidengan kode IS-PB-A1, IS-PB-A2, IS-PB-A3, IS-PB-T1, IS-PB-T2, IS-PB-B1, IS-PB-B2.

\begin{tabular}{cccc}
\hline Kode sampel & $\begin{array}{c}\text { Diameter zona } \\
\text { hambat }(\mathbf{m m})\end{array}$ & Berat ekstrak $(\mathbf{g})$ & Rendemen $(\% \mathbf{b} / \mathbf{v})$ \\
\hline IS-PB-A1 & 12,2 & 0,259 & 0,142 \\
IS-PB-A2 & 11,5 & 0,147 & 0,080 \\
IS-PB-A3 & 12,2 & 0,139 & 0,764 \\
IS-PB-T1 & 9,7 & 0,274 & 0,151 \\
IS-PB-T2 & 13,6 & 0,009 & 0,005 \\
IS-PB-B1 & 11,9 & 0,092 & 0,051 \\
IS-PB-B2 & 11,5 & 0,066 & 0,037 \\
\hline
\end{tabular}

Uji antagonis dengan kontak langsung antara bakteri dan fungi tanah untuk mengetahui potensi awal isolat fungi dalam menghambat pertumbuhan bakteri sebelumnya telah dilakukan oleh Wibowo et al(2017) dengan mengamati diameter zona hambat yang dihasilkan di sekitar fungi. Senyawa aktif yang disekresi fungi akan menyebar pada media agar yang telah diberi bakteri uji, sehingga bakteri uji pertumbuhannya akan terhambat jika berinteraksi dengan senyawa aktif yang memiliki aktivitas antibakteri sehingga menyebabkan terbentuknya zona bening (Mu'azzam et al., 2015). Zona hambat yang diperoleh dari kode sampel IS-PB-B1 diduga bisa karena menunjukkan zona yang tidak bening sempurna atau buram. Hal tersebut dapat disebabkan karena perkembangan fungi dan ketebalan fungi yang dikontakkan terhadap bakteri. Selain itu zona hambat yang berbeda pada masing-masing kode sampel dapat disebabkan oleh kemungkinan perbedaan kandungan fungi dalam setiap hasil isolasi fungi tanah. Setiap fungi memiliki kemampuan berbeda-beda dalam menghasilkan metabolit sekunder yang diduga sebagai bioaktif untuk menghambat pertumbuhan bakteri (Calvo et al., 2002).

\subsection{Fermentasi dan ekstraksi fungi tanah}

Fermentasi dilakukan untuk memperbanyak kultur massa fungi tanah sehingga diperoleh produk metabolit primer dan sekunder lebih banyak. Proses pembentukan metabolit sekunder ditandai dengan perubahan warna media PDB seiring bertambahnya waktu fermentasi. Mayoritas senyawa aktif dari fungi tanah merupakan metabolit sekunder yang 
diperoleh melalui proses fermentasi, dimana produksinya terjadi pada fase stasioner. Pada fase ini pertumbuhan fungi memasuki fase stagnan sehingga akumulasi produk fermentasi dan menipisnya nutrisi dapat mengubah kondisi dan keseimbangan mikrobiota dalam fermentor untuk waktu yang lebih lama. Jumlah nutrisi medium yang cenderung menipis memungkinkan sel fungi mempunyai komposisi dan menghasilkan bioproduk yang berguna untuk kelangsungan hidup fungi tanah atau metabolit sekunder (Fengxue et al., 2019). Proses fermentasi dilakukan hingga hari ke-14 karena di hari tersebut fungi mencapai pertumbuhan optimum dan berada dalam fase stasioner. Pada fase stationer populasi sel fungi tetap karena jumlah sel fungi yang tumbuh sebanding dengan jumlah sel fungi yang mati disebabkan oleh menipisnya nutrisi yang ada di dalam media (Jain \& Pundir, 2011). Hasil fermentasi diekstraksi menggunakan pelarut etil asetat 1:1.Proses ekstraksi tersebut menunjukkan perolehan rendemen yang disajikan pada Tabel 3.

Data randemen ekstrak menunjukkan sampel kode FE-PB-A3 memiliki nilai rendemen terbesar $(0,764 \% \mathrm{~b} / \mathrm{v})$, sedangkan rendemen terkecil diperoleh dari sampel kode FE-PB-T2 $(0,005 \% \mathrm{~b} / \mathrm{v})$.Ektrak FE-PB-T2 memiliki rendemen terendah dimungkinkan karena kandungan senyawa yang tersari oleh etil asetat dalam ekstrak lebih sedikit dibandingkan dengan sampel lainnya. Perbedaan nilai rendemen yang didapat dipengaruhi oleh kemungkinan perbedaan spesies fungi yang terkandung dalam setiap sampel. Spesies fungi yang berbeda memiliki adaptasi terhadap lingkungan yang berbeda pula. Media PDA air laut yang digunakan diduga mempengaruhi pertumbuhan fungi dalam setiap sampel. Kandungan $\mathrm{NaCl}$ yang lebih tinggi di dalam air laut menyebabkan tidak semua fungi dapat tumbuh, hanya fungi yang mampu beradaptasi dengan salinitas tinggi yang dapat terus tumbuh dan menghasilkan metabolit sekunder (Sepcic et al., 2011). Selain itu kemungkinan perbedaan spesies fungi juga menyebabkan perbedaan perkembangan sel dan perbedaan kemampuan untuk biosintesis metabolit sekunder (Calvo et al., 2002).

\subsection{Skrining fitokimia}

Nagwa et al(2018) melaporkan isolat fungi tanah yang diambil dari tanah rizosfer memiliki aktivitas antibakteri dengan kandungan terpenoid sebesar 38,34\%. Terpenoid merupakan senyawa yang mampu bertindak sebagai antibakteri dengan mengganggu membran lipid sehingga menyebabkan kebocoran dari liposom (Mujeeb \& Oathak, 2014). Berdasarkan hasil penelitian sampel tanah Wonorejo Surabaya oleh Arisanti et al (2012), didapatkan bahwa fungi khamir yang berhasil diisolasi mengadung senyawa fenolat yang memiliki aktivitas antibakeri. Fenolat merupakan golongan senyawa yang mampu mendenaturasi protein dinding maupun membran sel bakteri. Skrining fitokimia yang 
dilakukan pada ekstrak hasil fermentasi fungi tanah muara ini dilakukan dengan metode kromatografi lapis tipis (KLT) dan prinsip penampak noda yang sesuai. Fase gerak yang digunakan yaitu diklorometana : metanol (9:1). Eluen tersebut dipakai untuk mendeteksi kemungkinan golongan senyawa yang terkandung dalam ekstrak hasil fermentasi. Berdasarkan hal tersebut kondisi analisis yang didapat yaitu fase diam silika gel $60 \mathrm{~F}_{254}$ dan fase gerak diklorometan : metanol (9:1) dengan penampak noda sesuai dengan golongan senyawa yang diuji.

Hasilpenelitian yang diperoleh semua sampel negatif mengandung fenolat, namun positif terhadap uji kandungan terpenoid. Hal tersebut menunjukkan fungi tanah dalam penelitian ini mengandung senyawa golongan terpenoid yang berpotensi untuk menghambat pertumbuhan bakteri (Savitri et al, 2020). Skrining fitokimia lebih lanjut kemudian diperlukan untuk menentukan senyawa aktif yang berperan besar dalam menghambat pertumbuhan bakteri. Senyawa yang memiliki peran besar dalam menghambat aktivitas antibakteri dapat diidentifikasi kembali dengan profiling menggunakan HPLC (Sundari, 2010).

\subsection{Uji aktivitas antibakteri}

Ekstrak etil asetat fungi tanah muara dari 7 hasil isolasi khamir diuji aktivitas antibakterinya terhadap $P$. aeruginosa menggunakan metode mikrodilusi cairkonsentrasi tunggal $100 \mu \mathrm{g} / \mathrm{mL}$.Perolehan nilai persentase penghambatan disajikan pada Gambar 4.

Data persen penghambatanmenunjukkan bahwa ekstrak etil asetat fungi tanah muara memiliki aktivitas antibakteri terhadap P. aeruginosa. Kode sampel IS-PB-A2 menunjukkan nilai persen penghambatan tertinggi $(84,7 \pm 1,4 \%)$ sedangkan nilai persen penghambatan terendah dihasilkan oleh sampel dengan kode IS-PB-T2 $(30,5 \pm 3,3 \%)$. Uji aktivitas antibakteri pada penelitian ini bertujuan untuk menentukan persentase penghambatan bakteri dengan berpedoman pada standar yang ditetapkan oleh CLSI. Media yang direkomendasikan oleh CLSI untuk pengujian mikrodilusi adalah CAMHB. CAMHB merupakan media yang dibuat dengan penambahan ion $\mathrm{Mg}^{2+}$ dan $\mathrm{Ca}^{2+}$ ke dalam media MHB. Konsentrasi kation divalen seperti $\mathrm{Mg}^{2+}$ dan $\mathrm{Ca}^{2+}$ merupakan variabel penting yang perlu diperhatikan karena berpengaruh terhadap kestabilan dinding sel bakteri yang berakibat pada berkurangnya pengikatan gentamisin terhadap P.aeruginosa. Media MHB yang ditambah dengan kation akan menghasilkan MIC gentamisin \pm 32 kali lipat lebih tinggi dibandingkan pada media MHB tanpa penambahan kation (Fass \& Bernishan, 1979).

Uji aktivitas dalam penelitian ini dilakukan terhadap ekstrak hasil fermentasi fungi tanah yang diduga mengandung terpenoid. Semakin besar kandungan senyawa terpenoid dalam ekstrak dimungkinkan potensi hambatan terhadap bakteri akan lebih besar. Proses ini 
dapat terjadi karena senyawa terpenoid menyebabkan kebocoran liposom pada bakteri yang dapat mengganggu pembentukan membran lipid bakteri P.aeruginosa sebagai bakteri uji (Mujeeb \& Oathak, 2014) Hal tersebut ditunjukkan oleh hasil skrining fitokimia yang diperoleh. Perbedaan nilai persen penghambatan yang diperoleh dari metode mikrodilusi menggunakan ekstrak fungi dengan hasil uji antagonis menggunakan hasil isolasi fungi dapat dipengaruhi oleh laju pembentukan metabolit sekunder yang berbeda pada tiap fungi. Dimungkinkan jenis fungi yang terkandung dalam ekstrak tersebut memiliki spesies yang berbeda-beda. Setiap spesies fungi memliki kemampuan berbeda-beda dalam membentuk metabolit sekunder. Pembentukan metabolit sekunder dapat dipengaruhi beberapa faktor. Faktor yang berpengaruh seperti diferensiasi atau perkembangan sel, pengaruh sejumlah faktor eksternal (media pertumbuhan) dan internal (transduksi sinyal yang mengatur biosintesis produk alami), reaksi enzimatik sekuensial yang diperlukan untuk mengubah building blocks primer menjadi produk alami, regulasi ekspresi gen enzimatik produk alami oleh satu atau lebih aktivator transkripsional, biosintesis produk alami dengan metabolisme primer (Calvo et al., 2002).

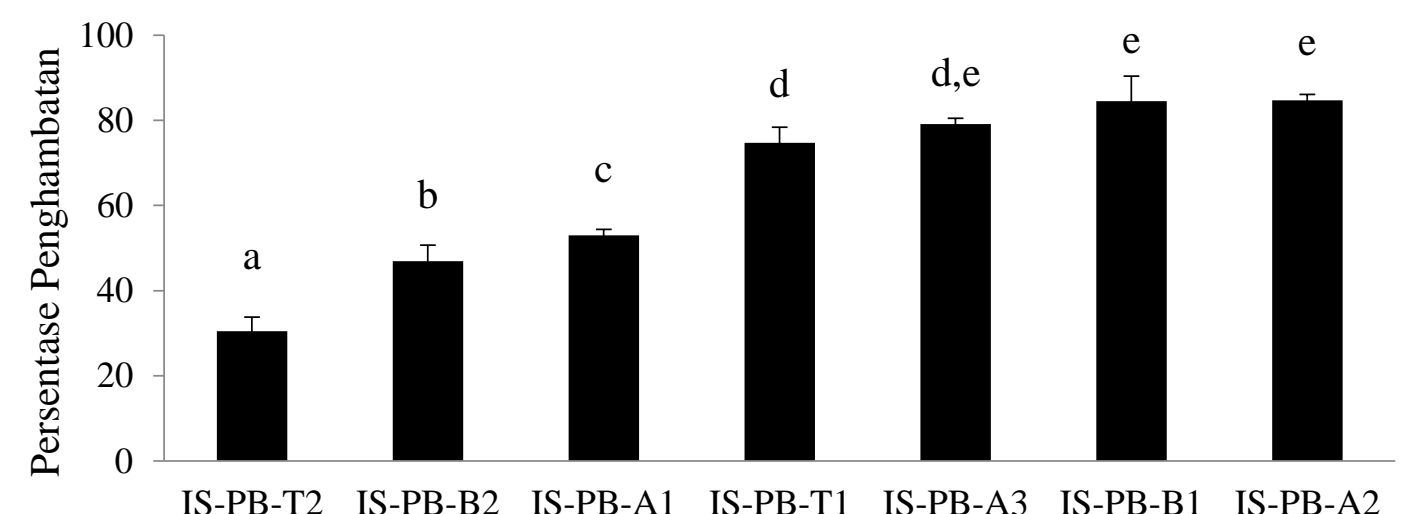

Ekstrak hasil fermentasi fungi tanah

Gambar 4.Diagram persentase penghambatan pertumbuhan bakteri P.aeruginosa oleh ekstrak fungi tanah muara dari yang terkecil hingga terbesar. Huruf yang sama menunjukkan tidak ada perbedaan signifikan $(p>0,05)$ antar kelompok uji. Data ditransformasi dengan Ln dan dianalisis menggunakan ANOVA.

Penelitian sebelumnya menunjukkan banyak fungi yang diisolasi dari tanah memiliki aktivitas menghambat pertumbuhan bakteri (Pamungkas et al, 2021). Ekstrak kode IS-PB-A2 menjadi isolat yang paling potensial karena memiliki nilai persen penghambatan tertinggi dibandingkan dengan isolat lainnya, yaitu sebesar 84,7 $\pm 1,4 \%$ dengan konsetrasi uji 100 $\mu \mathrm{g} / \mathrm{mL}$. Berdasarkan nilai persen penghambatan dan data analisis statistik persen penghambatan kode sampel IS-PB-A2 $(84,7 \pm 1,4 \%)$ dengan IS-PB-B1 $(84,5 \pm 5,9 \%)$ dan ISPB-A3 $(79,1 \pm 1,4 \%)$ dengan IS-PB-T1 $(74,7 \pm 3,7 \%)$ didapatkan hasil yang tidak berbeda 
signifikan ( $\mathrm{p}>0,05)$. Hal tersebut dimungkinkan sampel dengan kode IS-PB-A2 dan IS-PB-B1 memiliki jenis fungi atau kandungan senyawa bioaktif yang sama sehingga menunjukkan hasil tidak berbeda signifikan, begitu pula dengan sampel kode IS-PB-A3 dan IS-PB-T1. Pengujian aktivitas antibakteri menunjukkan sampel ekstrak fungi tanah yang diisolasi dari tanah muara Pelabuhan Besuki Situbondo dapat dinyatakan memiliki aktivitas antibakteri, namun belum bisa disimpulkan aktivitasnya karena dibutuhkan penelitian lebih lanjut terkait nilaiMIC dari masing-masing sampel.

\section{Kesimpulan}

Tujuhhasil isolasi fungi berhasil didapatkan termasuk dalam jenis khamir dengan kode sampel IS-PB-A1, IS-PB-A2, IS-PB-A3, IS-PB-T1, IS-PB-T2, IS-PB-B1, dan IS-PB-B2. Semua hasil isolasi fungi tanah tersebut memiliki aktivitas antibakteri terhadap P.aeruginosa.Uji aktivitas antibakteri dengan konsentrasi tunggal ekstrak etil asetat hasil fermentasi fungi tanah terhadap P.aeruginosa menghasilkan persen penghambatan IS-PB-A1 $53,0 \pm 1,4 \%$, IS-PB-A2 84,7 \pm 1,4\%, IS-PB-A3 79,1 \pm 1,4\%, IS-PB-T1 74,7 \pm 3,7\%, IS-PBT2 30,5 $\pm 3,3 \%$, IS-PB-B1 84,5 $\pm 5,9 \%$, IS-PB-B2 46,9 $\pm 3,8 \%$.

\section{Ucapan Terimakasih}

Penulis mengucapkan terimakasih kepadaDrug Utilisation and Discovery Research Groups(DUDRG) Fakultas Farmasi Universitas Jember atas dukungan fasilitas penelitian.

\section{Deklarasi Konflik Kepentingan}

Semua penulis menyatakan tidak ada konflik kepentingan terhadap naskah ini.

\section{Daftar Pustaka}

Anupama, B., C. Sonia, and K. Kamalpreet. (2017). Production of antibacterial agent from fungi isolated from park soil sample by fermentation under optimazed condition. International Journal of Research in Pharmaceutical Sciences, 8(1): pp.70-77.

Arisanti, S., Kwintasari, N., and Maya, S. (2012). Antimicrobial Assay of Soil Mold Isolates from Wonorejo Surabaya. The Journal for Technology and Science, 23(4): pp. 111-117

Calvo, A. M., Wilson, R. A., Bok J. W., dan Keller, N. P. (2002). Relationship between Secondary Metabolism and Fungal Development. Microbiology and Molecular Biology Review, 66(3): pp. 447.

Campbell, N., Reece, J. B., and Mitchell, L. (2003). BiologiJilid 2. Jakarta: Erlangga.

Clinical \& Laboratory Standards Institute (CLSI). (ss2012). Method for Dilution Antimicrobial Susceptibility Test for Bacteria That Grow Aerobically; Approved Standart - Ninth Edition. CLSI Document M07-A9. Wayne, PA: Clinical and Laboratory Standards Institute

Clinical \& Laboratory Standards Institute (CLSI). (2017). Performance Standarts for Antimicrobial Susceptibility Testing, 27 Edition. Wayne: CLSI supplement M100-S20. USA

Elliott, M., and Whitfield,A.K. (2011). Challenging paradigms in estuarine ecology and management. Estuarine, Coastal and Shelf Science, 94(4): pp.306-314.

Entwistle, E. M. (2018). Anthropogenic Nitrogen Deposition and Decomposer Fungi: Altered Composition and Function Fosters Greater Soil Carbon Storage. Applied and 
Environmental Microbiologi, 84(9): pp. 63-123

Fass, R. J., and Bernishan, J. (1979). Effect of Divalent Cation Cpncemtrations on the Antibiotic Susceptibility pf Nonfermenters Other than Pseudomonas aeruginosa. Antimicrobial Agents AndChemotherapy, 16(4):pp.434-438.

Fengxue, X., Dong, Welliang, Dai, Z. D., Jiang, Y., Yan, W., Lv, Z., Fang, Y., and Jiang, M. (2019). Biosynthetic Technology and Bioprocess Engineering. Current Developments in Biotechnology and Bioengineering. pp. 207-232. USA,Elsevier.DOI:10.1016/B978-0444-64085-7.00009-5

Jain, P., and Pundir, R. (2011). Effect of fermentation medium, ph and temperature variations on antibacterial soil dungal metabolite production. Journal of Agricultural Technology, 7(2): pp. 247-269.

Maulana, I.A., Triatmoko B., Nugraha, A.S.N., 2020. Skrining Fitokimia dan Uji Aktivitas Antibakteri Ekstrak dan Fraksi Tanaman Senggugu (Rotheca serrata (L.) Steane \& Mabb.) terhadap Pseudomonas aeruginosa.Journal of Pharmaceutical Science and Clinical Research(JPSCR), 5(1): pp. 01-11. 10.20961/jpscr.v5i1.32200

Mu'azzam, K. A. A., Taufiq, M., Azlina, N. I., Noorahzira, S., and Darah, I. (2015). Screening of antibacterial activity of endophytic fungi isolated from different leaf age ofCurcuma mangga using different growth media. International Journal of Research In Medical and Health Sciences, 4(9): pp. 24-28

Mujeeb, F. B. P., and Oathak, N. (2014). Phytochemical evaluation, antimicrobial acivity, and determination of bioactive components from leaves of Aegle marmelos. BioMed Research International, 13(52):pp.791-800.

Mustaqof, A., Wiharto, andSuryani, E. (2015). Sistem Pakar untuk Mendiagnosis Penyakit Infeksi Menggunakan Forward Chaining. Jurnal ITSMART, 4(1): pp.43-47.

Nagwa, E. A., Kassem, H. A., Hamed, M. A., El-Feky, A. M., Elnaggar, M. A. A., Mahmoud, K., and Ali, M. A. (2018). Isolation and characterization of the bioactive metabolites from the soil deriveded fungus Trichoderma viride. Journal of Fungi Biology, 9(1): pp.70-80.

Nursidika, P., Opstari, S., and Nurul, R. (2014). Aktivitas Antimikrob Fraksi Ekstrak Etanol Buah Pinang (Areca catechu L) padaBakteri Methicillin Resistant Staphylococcus aureus.Majalah Kedokteran Bandung,46(2):pp.94-99.

Pamungkas, F.B, Triatmoko, B., andNugraha, A. S. 2021. Penelusuran Dan Isolasi Fungi Tanah KabupatenSitubondo Serta Skrining Aktivitas Antibakteri terhadap Pseudomonas aeruginosa. Universitas Jember. Jurnal Kefarmasian Indonesia, 19(1): pp. 73-79.

Pepper, I. L., and Gentry, T. (2015). Earth Environment, $3^{\text {rd }}$ edition.Environmental microbiology, pp. 59-88. USA, Elsevier.

Queve, C. L., Plano, R. W., Pantuso, T., and Bannett, B. C. (2008). Effect of extracts from italian medicinal plants on planktonik growth, biofilm, formation and adherence of methicillin-resistant Staphylococcus aureus. Journal Of Ethnopharmacology, 118(3): p.418-428.

Savitri, G. R., Triatmoko. B., and Nugraha. A. S. 2020. Skrining Fitokimia dan Uji Aktivitas Antibakteri Ekstrak dan Fraksi Tumbuhan Anyang-Anyang (Elaeocarpus grandiflorus J. E. Smith.) terhadap Escherichia coli. Journal of Pharmaceutical Science and Clinical Research(JPSCR). 5(1): pp. 22-32. 10.20961/jpscr.v5i1.32206

Stuart B. L. (2014). The antimicrobial paradox: How miracle drugs are destroying the miracle.New York: Plenum Press.

Sepcic, K., Zalar, P., and Gunde-Cimerman, N. (2011). Low Water Activity Induces the Production of Bioactive Metabolites in Halophilic and Halotolerant Fungi. Marine Drugs, 9(1): pp. 43-58.

Sharifa, A. A., Jamaludin, J., Kiong, L. S., Chia, L. A., and Osman, K. 2012. Anti-Urolithiatic Terpenoid Compound from Malaysiana, 41(1): pp.33-39 
Sundari, I. (2010). Identifikasi Senyawa dalam Ekstrak Etanol Biji Buah Merah IDENTIFIKASI (Pandanus conoideus Lamk.).Skripsi: Universitas Sebelas Maret, Surakarta

Taslim, E. T. and T. T. Maskoen. 2016. Pola kuman terbanyak sebagai agen penyebab infeksi di intensive unit pada beberapa rumah sakit di indonesia. Anesthesia \& Critical Care.34(1): pp.56-62.

Volk, W., and Wheeker, M. (1971). Basic Microbiology6th edition. Harper \& Row Publisher.

WHO. (2017). Indonesia: Who Statistical Profile. World Health Organization on Behalf of the Special Progme for Research and Training in Tropical Diseases. Available from: https://apps.who.int/iris/rest/bitstreams/1081066/retrieve [Accessed 31 January 2020 ]

Wibowo, M., Julianti, E., and Muhammad, R. (2017). Isolation and Antibacterial of Soilderived Fungi from Taman Botani Negara Shah Alam Malaysia. Acta Pharmaceutica Indonesia, 42(1): pp. 18-24.

Zaman, S., Hossain, N., and Yasir Arafat, S. (2017). Management of newborn infection: Knowledge and attitude among health care providers of selected sub-district hospitals in Bangladesh. IJPPH, 1(2):pp.127-132.

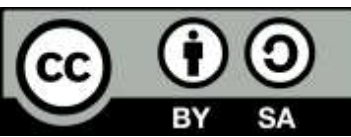

2021 by the authors. Submitted for possible open access publication under the terms and conditions of the Creative Commons Attribution-ShareAlike 4.0 International (CC BY-SA 4.0) license (https://creativecommons.org/licenses/by-sa/4.0/). 